\title{
Maddi Değerler Ölçeği’nin Türkçe’ye Uyarlanması
}

\section{Adaptation of the Material Values Scale to Turkish}

\author{
Doç. Dr. Gazanfer ANLI ${ }^{(i D} 1$
}

\begin{abstract}
$\ddot{\mathbf{O} z}$
Bu çalışmada, Richins (2004) tarafından geliştirilen Maddi Değerler Ölçeği’nin Türkçeye uyarlanması amaçlanmıştır. Bu araştırma kapsamında, 2018-2019 eğitim-öğretim yılında toplam 408 lisans ve yüksek lisans öğrencisinden oluşan bir araştırma grubu ile çalışılmıştır. Bu grup 203 kadın ve 205 erkekten oluşmaktadır. Ölçeğin Türkçeye çevrilme aşaması tamamlandıktan sonra gerekli izinler alınmış ve ölçek çalışma grubuna uygulanmıştır. Doğrulayıcı faktör analizi sonucunda uyum değerlerinin kabul edilebilir düzeyde olmamasından dolayı ölçeğin orijinal üç faktörlü yapısı doğrulanamamış ve Açımlayıcı Faktör Analizi yapılmasına karar verilmiştir. Yapılan analiz sonucunda her iki faktöre binişen ve eksi değer alan 2. maddenin çıkarılmasına karar verilmiştir. Sonuç olarak 8 madde ve 2 alt boyuttan oluşan bir yapı elde edilmiştir. Maddelerin faktör yük değerlerinin .43 ile .90 arasında değiştiği tespit edilmiştir. Doğrulayıc1 faktör analizi sonuçları iki faktörlü yapının iyi uyum değerlerine sahip olduğunu göstermiştir. Ölçeğin iki boyutunun da Cronbach alfa iç tutarlılık katsayısı .70 iken tüm ölçeğin Cronbach alfa iç tutarlılık katsayısı .77 olarak bulunmuştur. Yapılan bu çalışma neticesinde bu ölçeğin Türkçe formunun güvenilir ve geçerli olduğu çıkarımı yapılmıştır.
\end{abstract}

Anahtar Kelimeler: Maddi değerler, merkeziyet, başarı, mutluluk, geçerlik, güvenirlik

Makale Türü: Araştırma

\begin{abstract}
In this study, it was aimed to adapt the Material Values Scale developed by Richins (2004) to Turkish. For this purpose, a total of 408 undergraduate and master's students were the participants in 2018-2019 academic year. This group is composed of 203 women and 205 men. After the translation process of the scale into Turkish was finished, necessary permissions were obtained, and the scale was applied to the study group. Since the fit indices were not within acceptable limits in Confirmatory Factor Analysis and the original three-factor structure wasn't confirmed, it was decided to perform Exploratory Factor Analysis. Item 2 had a negative value and loaded on both factors, so it was decided to remove this item. As a result, a structure consisting of 8 items and 2 sub-dimensions was obtained. Factor loadings of the items were between .43 and .90 . Confirmatory factor analysis results indicated that the two-factor structure had good fit. Cronbach alpha coefficient of both of the two factors were.70 and the Cronbach alpha coefficient of the whole scale was .77. As a result of this study, it was concluded that the Turkish version of this scale is reliable and valid.
\end{abstract}

Keywords: Material values, centrality, success, happiness, validity, reliability

Paper Type: Research

${ }^{1}$ Bursa Teknik Üniversitesi, İnsan ve Toplum Bilimleri Fakültesi, anligazanfer@gmail.com.

Atıf için (to cite): Anl, G. (2020). Maddi Değerler Ölçeği'nin Türkçe’ye uyarlanması. Afyon Kocatepe Üniversitesi Sosyal Bilimler Dergisi, 22(3), 624-634. 


\section{Giriş}

Küreselleşen dünyada maddi değerler ve onlara verilen önem dikkat çekici hale gelmektedir. Bu konu, alanda çalışan bazı uzmanların ilgisini çekmiş ve araştırmalarına maddi değerleri ve onun etkilerini konu etmişlerdir. Maddi değer konusundaki tanımlardan önce değerin tanımını yapmak daha uygun olacaktır. Milton Rokeach, değer kavramını "belirli bir davranış ve varoluş durumlarına yönelik eylem ve yargıları yönlendiren merkezi konumda yer alan kalıcı inanç” olarak tanımlamıştır (Rokeach 1968, s. 161). Değerlerin birey düzeyinde, kişilerin gereksinimleri ile toplumun talepleri arasında bir denge unsuru olan içselleştirilmiş standartlar olduğu; toplum düzeyinde ise değerlerin, anlam, bütünleşme ve istikrar getiren ortak anlayışları temsil ettiği bildirilmiştir (Braithwaite ve Blamey, 1998). İnsanların taşınır veya taşınmaz mallar edinmesi ve tüketimin artması ile birlikte bireylerin edindiği eşyalara verdiği önem ve maddi değerler konusu çalışılmaya başlanmıştır (Browne ve Kaldenberg, 1997; Griffin, Babin ve Christensen, 2004).

Maddi değerler konusunda bilimsel açıdan öncü sayılabilecek olan Csikszentmhalyi ve Rochberg-Halton (1981), varlık edinme ile oluşan bağl1lıkları ve ilişkileri vurgulayan bir maddecilik (materyalizm) modeli sunmuşlardır. Bu model, sadece nesnelerin türlerini ve fiziksel doğasını değil, aynı zamanda bireye hizmet ettikleri amacı ve daha özgül olarak bir bireyin yapmasını sağladıkları şeyi de içerir. Csikszentmhalyi ve Rochberg-Halton (1978), maddeciliği amaçsal (terminal) ve araçsal (instrumental) olmak üzere ikiye ayırmıştır. Amaçsal maddecilikte, bireyler varlıklara sahip olmayı arzu eder ve onların tüm gayesi de budur. Araçsal maddecilik ise bize bir şeyi yapabilmemizi sağlayacak, örneğin bir ilişki kurmamızı sağlayan ya da kendini gerçekleştirme konusunda bizi cesaretlendirebilecek bir nesneye sahip olma arzusunu içerir. Bu yüzden araçsal maddecilik hayatın daha uzun, daha güvenli, keyif sağlayıcı olmasına yardım eder (Csikszentmhalyi ve Rochberg-Halton, 1978). Belk (1985) ise maddeciliği bir dizi kişilik özelliği olarak görmüş ve tüketici temelli bir yaklaşımla ele alarak onu "tüketicinin dünyevi varlıklara verdiği önem" olarak tanımlamıştır (Belk, 1985, s. 291). Belk’e göre maddecilik kıskançlık, cimrilik ve sahip olma isteği gibi kişilik özelliklerini barındırmakta ve bireylerin hayatlarının merkezinde yer alıp onların hayattan haz alıp almamalarını etkilemektedir. Richins ve Dawson (1992) ise "maddi varlıklara sahip olma arzusunu merkeze alan bir grup inanç" veya "bireylerin hayatlarında kazandığı ya da sahip olduğu varlıklara ilişkin göreceli önem hakkındaki zihin yapısı ya da tutum kümesi” olarak tanım yapmışlardır (Richins ve Dawson, 1992, s. 307). Bu yazarlara göre maddecilik, Belk' in (1985) belirttiği gibi bir kişilik özelliği olmaktan ziyade yaşam boyunca değişiklik gösterebilen sosyal değerler bütünüdür. Ayrıca bu yazarlar, bu kavramın üç boyutu olduğunu, bu üç boyutun ise, merkezilik, başarı ve mutluluk olarak kaydedildiğinden bahsetmişlerdir.

Merkezilik boyutu, maddeci bireylerin mallarının ve eşyalara sahip olma durumunun onların hayatına amaç ve anlam katma ölçüsünde hayatlarında yer alma derecesidir. Bireyler böylece günlük uğraşları için bir hedef oluşturup yaşamlarına bir ölçüde anlam katmaya çabalamaktadır (Richins ve Dawson, 1992). İkinci boyut olan başarı boyutu, maddeci kimselerin sahip oldukları malların nitelik ve niceliğine göre kendileri ya da başkalarını yargılamaya tabi tutmalarıdır. Bireyler sağlam maddi varlıklara sahip olduklarında, bu kazanım ya da sahipliklerin kendilerini başarıya götürecek bir anahtar niteliğinde olduğuna inanmaktadır (Richins, 1994). Son boyut olan mutluluk boyutu ise, mal edinmelerinin onların mutluluk ve yaşam doyumlarının en büyük kaynağı olduğu ile ilgili inançlarıdır. Yüksek düzeyde maddeci bakış açısına sahip bireyler, kişisel ilişkiler, deneyimler gibi etmenlerden çok kendilerinin kazandığ varlıklarla mutluluğun geleceğini düşünmektedir (Richins, 2004, s. 209; Richins ve Dawson, 1992, s. 2).

Yapılan alan yazın taramasında maddi değerleri ölçen, çocuk veya ergen grubu için, Goldberg ve diğerleri'nin (2003) Genç Maddecilik Ölçeği; Opree, Buijzen, Reijmersdal ve Valkenburg'un (2011) Çocuklar İçin Maddi Değerler Ölçeği bu konuda geliştirilmiş güncel ölçeklerdir. Yetişkinler için Hanzaee ve Adibifar (2012) tarafından geliştirilen 43 maddelik bir 
Maddi Değerler Ölçeği de bulunmaktadır. Ancak konuya ilişkin yapılan araştırmalarda daha çok Richins ve Dawson (1992) tarafindan geliştirilen 18 ifadeden ve üç boyuttan oluşan ve ikincisi yine Richins (2004) tarafından geliştirilen 9 ve 15 maddelik, üç boyuttan oluşan "Maddi Değerler Ölçeğì"nin yer aldığı görülmektedir. Richins'in (2004) ölçeğinin, Fransız ve Rus (Griffin vd., 2004), Alman (Müller vd., 2013) ve Hirvat dillerinde (Lipovčan, Prizmić-Larsen, ve Brkljacic, 2015) test edilip geçerlik ve güvenirliğinin sağlandığı rapor edilmiştir. Çalışmamızda 15 maddelik kısa form yerine 9 maddelik kısa form tercih etmemizin sebebi ise, yapılan çalışmalarda 15 maddelik formda yer alan altı adet ters maddenin farklı kültürlerde farklı yanıtlara sebep olduğunun raporlanmasıdır (Wong, Rindfleisch ve Burroughs, 2003).

\section{Araştırmanın Amacı ve Önemi}

Bu araştırmanın amacı, Richins (2004) tarafından geliştirilen "Maddi Değerler Ölçeği" nin Türkiye koşullarında geçerlik ve güvenirlik çalışmasını yapmaktır. Ekonomik gücü elinde bulunduran on sekiz yaş ve üstü bireylerin maddiyat konusundaki görüşlerini ölçme ihtiyac1 vardır. $\mathrm{Bu}$ konuda ülkemizde de yetişkin grubu için maddi değerleri ölçen bir ölçme aracı bulunmamaktadır. Alan yazınımızda bu tarz bir ölçeğe rastlanmadığı için Richins (2004) tarafından geliştirilen Maddi Değerler Ölçeği'nin uyarlanmasına karar verilmiştir. Bu ölçek yukarıda da bahsedildiği gibi farklı birçok ülkedeki örneklemlerde test edilmiş olup geçerlilik ve güvenilirliği sağlandığı için ve ayrıca 9 maddeyi içeren kısa ve kullanışlı bir formda olması hasebiyle tercih edilmiştir. Bu alanda çalışan saha araştırmacıları ve uzmanların ölçekten faydalanabilmesi amaçlanmakta, bu konuda yapılacak farklı araştırmalarda ölçeğin kullanımının gerçekleştirilebileceği düşünülmektedir. Ayrıca ölçeğin, maddi değerler konusunda bilgilendirme ve farkındalık oluşturması hedeflenmektedir. Son olarak ölçeğin kısa oluşu uygulanma ve değerlendirilme açısından kolaylık sağlayacağı için konu ile ilişkili çalışmalarda rahatlıkla kullanılabileceği tahmin edilmektedir.

\section{Yöntem}

\subsection{Araştırmanın Metodu}

$\mathrm{Bu}$ araştırmada ölçek uyarlama çalışması niteliğinde olan betimsel tarama modeli tercih edilmiştir. Çalışma, Richins (2004) tarafindan geliştirilen "Maddi Değerler Ölçeği"nin Türk kültürüne uyarlanması işlemlerini içermektedir.

\subsection{Veri Toplama Araçları}

Sosyodemografik Form: Öğrencilerden yaş ve cinsiyet bilgilerini içeren bir form doldurmaları istenmiştir.

Maddi Değerler Ölçeği: Richins (2004) tarafından geliştirilen "Maddi Değerler Ölçeği”" dokuz madde ve üç alt boyuttan oluşmaktadır ve 5'li Likert tipi bir ölçektir. Bu alt boyutlar "Merkezilik, "Başarı" ve "Mutluluk" olarak belirlenmiştir. Merkezilik alt boyutu için "Bir şeyler satın almak bana çokça keyif veriyor", başarı alt boyutu için "Pahalı ev, araba ve kıyafeti olan insanlara hayranım", mutluluk alt boyutu için ise "Daha çok şey satın almaya gücüm yetseydi daha mutlu olurdum" maddeleri örnek verilebilir. 9 maddelik ölçeğin Cronbach alfa iç tutarlılik katsayıs1 .84 olarak bulunmuştur. Doğrulayıcı faktör analizi sonucu uyum değerleri ise TLI= .966, $\mathrm{CFI}=.977$ ve $\mathrm{RMSEA}=.053$ olarak tespit edilmiştir.

Oxford Mutluluk Ölçeği Kısa Formu-OMÖ-K: Ölçek Hills ve Argyle (2002) tarafindan geliştirilmiş, Türk kültürüne Doğan ve Çötok (2011) tarafindan uyarlanmıştır. Ölçek yedi maddeden oluşan tek faktörlü bir yapıya sahip olup 5'li Likert tiptedir. Ölçeğin uyarlama çalışmasında elde edilen tek boyutlu yapı toplam varyansın \%39,74'ünü açıklamıştır. Ayrıca doğrulayıcı faktör analizi sonucunda da uyum değerlerinin iyi olduğu görülmüştür $\left(x^{2} / \mathrm{df}=2.27\right.$, $\mathrm{RMSEA}=.074, \mathrm{GFI}=.97, \mathrm{CFI}=.95, \mathrm{NFI}=.97)$. Ölçeğin güvenirlik çalışmalarından elde edilen sonuçlara göre Cronbach alfa katsayısı .74, test tekrar test katsayısı ise .85 olarak tespit edilmiştir. $\mathrm{Bu}$ çalışma kapsamında ölçeğin Cronbach alfa katsayısı .72 olarak bulunmuştur. 


\section{3. Ölçek Uyarlama Çalışmaları}

Çalışmada öncelikle Richins (2004) tarafından geliştirilen "Maddi Değerler Ölçeği ile ilgili yazarla e-posta vasıtası ile iletişime geçilmiş ve gerekli izinler alınmıştır. Sonrasında ölçek psikolojik danışma ve rehberlik bölümünde görev yapan üç uzman tarafindan Türkçeye çevrilmiş, daha sonra çevrilen Türkçe form İngilizce Öğretmenliği mezunu iki uzman tarafından tekrar İngilizceye çevrilmiştir. İki form arasında kontroller yapılmış ve ölçeğin çevrilmiş formu dilsel eşdeğerlik açısından teyit edilmiştir. En son olarak psikolojik danışma ve rehberlik bölümü yüksek lisans öğrencisi olan üç kişi ölçeğin açıkça anlaşılır ve uygulanabilir olduğu noktasında görüş belirtmişlerdir. Böylece ölçeğin son hali uygulamaya hazır hale gelmiştir.

\section{4. Çalıșma Grubu}

$\mathrm{Bu}$ araştırmanın evrenini 2018-2019 eğitim-öğretim yılında Bursa Teknik Üniversitesi'nde öğrenim gören 4667 öğrenci oluşturmaktadır. Örneklem ise, yine üniversitenin çeşitli lisans bölümlerindeki birinci sınıf öğrencileri ve yüksek lisans ders dönemi öğrencilerinden oluşmaktadır. 203 kadın (\%49,8), $205(\% 50,2)$ erkek olmak üzere toplam 408 öğrenciden oluşan grubun yaş ortalaması ise 20,74 olarak tespit edilmiştir. Bu örneklem alınırken vakit, para vb. değişkenlerde kolaylık sağlaması açısından uygun örnekleme yöntemi tercih edilmiştir (Fraenkel, Wallen ve Hyun, 2012). Ölçekler uygulama izni alındıktan sonra öğrencilere ders saatlerinde ve gönüllülük prensibine dayalı olarak uygulanmıştır. Form uygulanmadan önce öğrencilere isim, soy isim vb. kendilerini tanıtıcı bilgileri vermeden formları doldurmaları gerektiği ve katılım konusunda herhangi bir tereddüt veya rahatsızlık duyduklarında bildirebilecekleri ve katılmaktan vazgeçebilecekleri açıklanmıştır.

\subsection{Verilerin Analizi}

Verilerin analizine geçmeden önce verilerin normallik sınırları içinde olup olmadığına çarpıklık ve basıklık değerleri aracılığı ile bakılmış, tüm değişkenlerin çarpıklık basıklık değerlerinin .35 ile -.42 aralığında olduğu tespit edilmiştir. Veri setinde -2 ile +2 arasındaki değerler normal kabul edildiğinden (Trochim ve Donnelly, 2006) verilerin uygun değerlerde olduğu görülmüştür. Geçerlilik çalışmasında doğrulayıcı faktör analizi ve açımlayıcı faktör analizi gerçekleştirilmiştir. Ayrıca ölçüt geçerliğinin sağlanması için ölçeğin Oxford Mutluluk Ölçeği Kısa Formu ile olan korelasyonu hesaplanmıştır. Ölçeğin yapı geçerliğine ek kanıt sağlamak için alt boyutların birbirleri ve tüm ölçekle olan korelasyonlarına bakılmıştır. Güvenirlik analizleri için Cronbach alfa iç tutarlılık katsayısı ve madde-toplam korelasyonlarından faydalanılmıştır. Ayrıca değişkenlere ilişkin aritmetik ortalama ve standart sapma değerleri de incelenmiştir. Tüm bu analizler SPSS 25 ve AMOS 24 paket programları ile gerçekleştirilmiştir.

\section{Bulgular}

\subsection{Geçerlik Bulguları}

Richins (2004) tarafindan geliştirilen 3 boyutlu ölçeğin yapı geçerliliğini sınamak için öncelikle doğrulayıcı faktör analizi yapılmıştır. Bu analizde uyum değerlerinin istenilen düzeyde olmadığ1 görülmüştür $(x 2 / \mathrm{sd}=5,54, p<.001$, RMSEA=.10, SRMR=.06, GFI=.92, AGFI=.86, $\mathrm{CFI}=83$, NFI=80, TLI=77). Bu sonucun yanında modelde yer alan "merkeziyet" ve "başarı" boyutları arasında korelasyon kestirimi değerinin oldukça yüksek çıkması da $(\Phi=0.99)$ bu iki boyut arasında neredeyse bir fark olmadığı çıkarımına yol açmıştır. Bu bulgu, ölçeği daha önce Fransiz ve Rus (Griffin, Babin ve Christensen, 2004), Alman (Müller vd., 2013) ve Hirvat (Lipovčan, Prizmić-Larsen, ve Brkljacic, 2015) kültürlerine uyarlayan araştırmacıların sonuçları ile de uyum arz etmektedir. Bu araştırmacılar da elde edilen bulgular ışığında merkeziyet ve başarı boyutlarını birleştirip tek boyut olarak ele almışlardır. Ayrıca yaptığımız doğrulayıcı faktör analizinde, 2. Maddenin faktör yükü .07 bulunmuştur. Bu sonuçlara göre ölçeğin orijinal 3 boyutlu yapısının Türk kültürü için doğrulanmadığı tespit edilmiştir. Bundan dolayı açımlayıcı faktör analizi yapılmasına karar verilmiştir. Bu analizde Kaiser-Meyer-Olkin (KMO) değeri 
incelenmiş ve .79 olarak bulunmuştur. Ayrica Barlett's Sphericity testi sonucu $\left(\chi^{2}=752,623\right.$, $p<.01$ ) da verilerin faktör analizine uygun olduğunu göstermiştir (Çokluk, Şekercioğlu ve Büyüköztürk, 2012). Bir sonraki adımda temel bileşenler analizi yapılmış ve bu işlem yapılırken yukarıda belirtilen literatür ışığında iki boyut sabitlenerek analiz gerçekleştirilmiştir. Bu boyutlar arası korelasyonun olduğu düşünüldüğünden Promax döndürme tekniği kullanılmıştır. Yapılan analiz sonucunda hem her iki faktöre binişen ve hem de eksi değer alan (.58 ve -.48) 2. maddenin çıkarılmasına karar verilmiştir (Çokluk, Şekercioğlu ve Büyüköztürk, 2012). Madde çıkarıldıktan sonra kalan 8 madde ile analiz tekrarlanmış ve 2 alt boyuttan oluşan bir yapı elde edilmiştir. Tablo 1 'de de görüldüğü üzere bu 8 maddenin öz değeri 1'den büyük olan iki farklı faktör altında bir araya geldiği ve faktörlerin toplam varyansın \% 53.262'sini açıkladığ 1 tespit edilmiştir.

Tablo 1. Elde edilen iki faktörün özdeğer ve varyansi açiklama yüzdeleri

\begin{tabular}{|c|c|c|c|c|c|}
\hline Faktör & Öz değer & $\begin{array}{l}\text { Açıklanan } \\
(\%)\end{array}$ & Varyans & $\begin{array}{l}\text { Y1 } \breve{g}_{1} l m a l_{1} \\
(\%)\end{array}$ & Varyans \\
\hline 1 & 3,157 & 39,457 & & 39,457 & \\
\hline 2 & 1,104 & 13,805 & & 53,262 & \\
\hline
\end{tabular}

Tablo 2'de belirtildiği üzere 5, 6, 7, 8 ve 9. Maddeler "Merkeziyet ve Başarı", 1, 3 ve 4. Maddeler ise "Mutluluk" alt boyutunu temsil etmektedir. Maddelerin faktör yük değerlerinin .43 ile .90 arasında değiştiği tespit edilmektedir. Faktör yüklerinin .40 ve üzeri olması tavsiye edildiğinden (Stevens, 1992), bu ölçütün sağlandığı açıça görülmektedir.

Tablo 2. Döndürme sonrası Maddi Değerler Ölçeğine (MDÖ) ait faktör yükleri

\begin{tabular}{lcc}
\hline \multirow{2}{*}{ Maddeler } & \multicolumn{2}{c}{ Faktör Yükü } \\
\cline { 2 - 3 } & 1. Faktör & 2. Faktör \\
\hline MDÖ 8 & .839 & \\
MDÖ 6 & .689 & \\
MDÖ 7 & .681 & \\
MDÖ 5 & .649 & .905 \\
MDÖ 9 & .429 & .740 \\
MDÖ 1 & & .661 \\
MDÖ 3 & & \\
MDÖ 4 & & \\
\hline
\end{tabular}

Daha sonra 8 madde ve iki boyutlu bu modeli test etmek için doğrulayıcı faktör analizine geçilmiştir. Bu analizde $x^{2} / \mathrm{sd}$, RMSEA, RMR, TLI, GFI, NFI, AGFI ve CFI değerleri ölçüt olarak alınmıştır. Doğrulayıcı faktör analizi sonuçlarında $x^{2} / \mathrm{sd}$, değerinin 3 'ten küçük, RMSEA değerinin .10'dan düşük, TLI, GFI, NFI, AGFI ve CFI'nın ise .90'a eşit ya da daha yüksek bir değer alması model ile veri uyumunun sağlandığını gösteren ölçütlerdir (Marsh, Balla ve McDonald, 1988). Bu ölçütler doğrultusunda uygulanan doğrulayıcı faktör analizi, sekiz madde ve iki faktörden oluşan yapının uyum değerlerinin iyi olduğunu göstermiştir $\left(x^{2} / \mathrm{sd}=2,29, p<.001\right.$, $\mathrm{RMSEA}=.05, \mathrm{SRMR}=.04, \mathrm{GFI}=.97, \mathrm{AGFI}=.95, \mathrm{CFI}=.97, \mathrm{NFI}=.94, \mathrm{TLI}=.95)$. Ölçekle alakalı path analizi sonucu oluşan değerler Şekil 1'de gösterilmiştir. 
Şekil 1. MDÖ’ye ilişkin yol şeması ve faktör yükleri

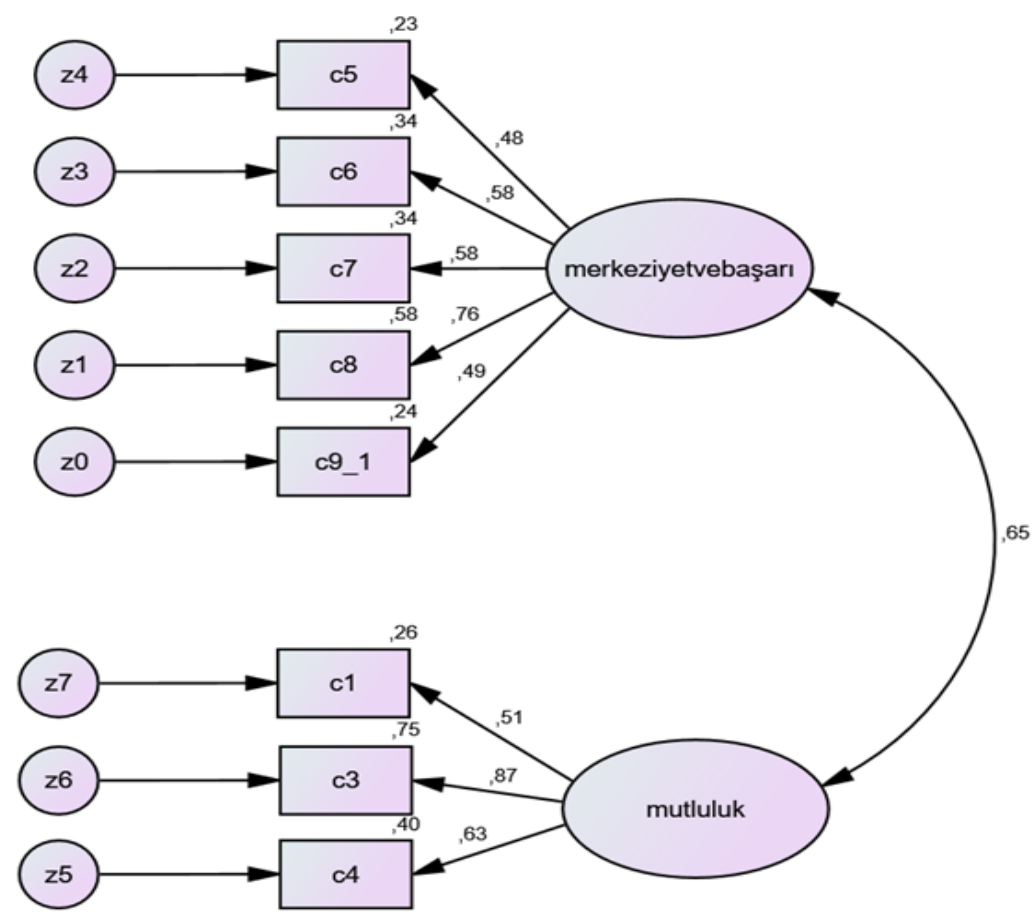

Ölçek boyutları arasındaki korelasyona bakıldığında ise Merkeziyet ve Başarı boyutu ile Mutluluk boyutu arasında pozitif yönde orta düzeyde anlamlı $(r=.49, p<.01)$ ilişki saptanmıştır. Ölçüt geçerliğini sınamak için Doğan ve Çötok (2011) tarafından Türk kültürüne uyarlanan Oxford Mutluluk Ölçeği Kısa Formu (Hills ve Argyle, 2002) kullanılmıştır. Korelasyon analizi sonucunda Maddi Değerler Ölçeği (MDÖ) ile Oxford Mutluluk Ölçeği Kısa Formu arasında negatif yönde düşük düzeyde anlamlı $(r=-15, p<.01)$ ilişki saptanmıştır. Ölçeklere ilişkin betimsel istatistikler ve korelasyon sonuçları Tablo 3 'te ayrıntılı bir biçimde gösterilmiştir.

Tablo 3. Maddi Değerler Ölçeği (MDÖ) ve alt boyutları ile Oxford Mutluluk Ölçeği'ne ait betimleyici istatistikler ve aralarındaki korelasyona dair sonuçlar

\begin{tabular}{lllll}
\hline Faktör & 1 & 2 & 3 & 4 \\
\hline 1. Maddi değerler ölçeği toplam puan & - & & & \\
2. Merkeziyet ve başarı & $.90^{* *}$ & - & & \\
3. Mutluluk & $.82^{* *}$ & $.49^{* *}$ & - & \\
4. Oxford mutluluk ölçeği & $-.15^{* *}$ & -.05 & $-.23^{* *}$ & - \\
Ortalama & 21.06 & 12.58 & 8.48 & 23.41 \\
Standart Sapma & 5.24 & 3.41 & 2.65 & 4.08 \\
Çarpiklık & .23 & .35 & .17 & -.41 \\
Basıklık & .01 & .01 & -.42 & .05 \\
Cronbach $\alpha$ & .77 & .70 & .70 & .72 \\
\hline
\end{tabular}

Tablo 3 incelendiğinde Maddi değerler ölçeği toplam puanı ve alt boyutlar olan merkeziyet ve başarı ile mutluluk ortalamalarının orta düzeyde olduğu görülmüsstür. Ayrıca Oxford mutluluk ölçeği puan ortalamalarının da yine orta düzeyin hafif üzerinde olduğu tespit edilmiştir. Maddi değerler ölçeği toplam puanı ve ölçeğin mutluluk alt boyutu Oxford mutluluk ölçeği ile negatif yönlü düşük düzeyde anlamlı ilişkiye sahipken, merkeziyet ve başarı alt boyutu Oxford mutluluk ölçeği ile anlamlı bir ilişkiye sahip değildir. Maddi değerler ölçeği'nin alt boyutları olan mutluluk ile merkeziyet ve başarı boyutu arasındaki ilişki orta düzeyde ve anlamlı olarak bulunmuştur. Yine bu alt boyutlar, ölçeğin toplam puanları ile yüksek düzeyde ve anlamlı 
ilişkilidir. Ölçek alt boyutları arasında çok yüksek ya da çok düşük bir korelasyonun olmaması ve alt boyutların tüm ölçek puanı ile yüksek düzeyde ilişkiye sahip olması da geçerlilik için ek kanıtlardır (Tavşancıl, 2010).

\subsection{Güvenirlik Bulguları}

Ölçeğin güvenirliğini saptamak için Cronbach Alfa iç tutarlılık kat sayısı analiz edilmiştir. Ölçeğin iki boyutunun da Cronbach alfa katsayısı .70, tüm ölçeğin Cronbach alfa katsayısı .77 bulunmuştur. Ayrıca ölçeğin düzeltilmiş madde-toplam korelasyonlarının .36 ile .61 arasındaki değerlere sahip olduğu tespit edilmiştir. Bu değerler Tablo 4'te gösterilmiştir.

Tablo 4. Güvenirlik analizi sonuçları

\begin{tabular}{llll}
\hline Madde No & $\begin{array}{l}\text { Düzeltilmiş Madde toplam } \\
\text { korelasyonu }\end{array}$ & $\begin{array}{l}\text { Madde atıldığında } \\
\text { Cronbacha Alfa }\end{array}$ & Cronbach Alfa \\
\hline M1 & .36 & .77 & \\
M3 & .61 & .72 & \\
M4 & .53 & .74 & .77 \\
M5 & .40 & .76 & \\
M6 & .46 & .75 & \\
M7 & .47 & .75 & \\
M8 & .57 & .74 & \\
M9 & .43 & .76 & \\
\hline
\end{tabular}

Tablo 4 incelendiğinde, ilk boyuttaki madde-toplam korelasyonlarının .36 ile .61 arasında olduğu, ikinci boyuttaki maddelerin madde-toplam korelasyonlarının ise .40 ile .57 arasında yer aldığı görülmüştür. Ölçekteki tüm maddelerin madde-toplam korelasyonları için kabul edilebilir değer olan .30'dan yüksek olduğu tespit edilmiştir (Büyüköztürk, 2011).

\section{Tartışma}

Araştırmanın amacı Richins (2004) tarafından bireylerin maddi değer ve mal varlıklarına verdikleri önemi ölçmek için geliştirilen Maddi Değerler Ölçeği’ni Türk kültürüne uyarlamak ve alanda yapılacak çalışmalara katkı sağlamaktır. Şimdiye kadarki alan yazın taramamız sonucunda bu ölçeğin kısa formunun ülkemizdeki ilk uyarlanma çalışması olduğunu belirtebiliriz. Ölçeğin orijinal yapısında yer alan "mutluluk", "merkeziyet" ve "başarı" boyutlarının olduğu üç faktörlü model, gerçekleştirdiğimiz doğrulayıcı faktör analizi sonucunda doğrulanmamıştır. Bu sonucun yanında modelde yer alan "merkeziyet" ve "başarı" boyutları arasında korelasyon kestirimi değerinin oldukça yüksek çıkması da $(\Phi=0.99)$ bu iki boyut arasında neredeyse bir fark olmadığı çıkarımına yol açmıştır. Bu bulgu ölçeği daha önce Griffin ve diğerlerinin (2004) 103 kişilik bir Rus örneklemi ile ölçeğin 18 maddelik formunu kullandığ 1 çalışmada, Müller ve diğerlerinin (2013) 2520 kişilik Alman örneklemi ile ölçeğin 15 maddelik formunu kullandığı çalışmada ve Lipovčan ve diğerlerinin (2015) 1129 kişilik Hırvat örneklemi ile ölçeğin 9 maddelik formunu kullandığ 1 çalışmada elde edilen sonuçlar ile de uyum arz etmektedir. Bu araştırmacıların elde ettiği bulgularda da mutluluk boyutu hiç değişmeden aynen kalmış, merkeziyet ve başarı boyutları birleşip tek boyut içerisinde yer almışlardır.

Uyarladığımız bu ölçeğin mutluluk boyutunu oluşturan "Daha çok şey satın almaya gücüm yetseydi daha mutlu olurdum", "Sahip olmadığım bazı şeylere sahip olsam hayatım daha iyi olurdu" ve "Beğendiğim şeyleri satın almaya gücümün yetmemesi canımı sıkıyor" maddeleri sadece maddeci bir bakış açısı ile değil aynı zamanda bireylerin refah düzeyleri ile de ilişkilidir. Maddi durumu nispeten daha iyi olan bireylerde bu maddeler maddeci bakış açısını sergileyebilirken daha düşük gelire sahip bireylerde ise düşük gelir düzeyi ve düşük sosyoekonomik durumu yansıtabilir. Merkeziyet ve başarı boyutuna bakıldığında ise lüks eşyalara sahip olmaktan keyif alma, para harcayarak bir şeyleri satın almayı ve bu satın aldığı veya sahip olduğu varlıklarla başkalarını etkilemeyi amaç edinme vurgulanmaktadır. Birçok ülkede olduğu gibi bizim ülkemizde de ekonomik koşulları iyi olmayan bireyler var olduğundan, 
ölçeğin yapısı ve maddelerden alınan puanlar da bu koşul ve durumlardan etkilenmektedir. $\mathrm{Bu}$ konuda ölçek maddelerinin eşyaların kolayca elde edilebilir olduğu varsayımına dayanmasının dünyadaki tüm ülkelerde geçerli olamayacağı konusu tartışılmıştır (Griffin vd., 2004). Bu yüzden yukarıda bahsedilen çalışmalarda Rus, Alman ve Hırvat örneklemlerinde de merkeziyet ve başarı boyutlarının birleşmesi, ölçeğin yapısının belirtilen sebeplerle değişmesinin gerekçesi olabilir.

Ölçüt geçerliğini sınamak için yapılan korelasyon analizi sonucunda Maddi Değerler Ölçeği (MDÖ) ile Oxford Mutluluk Ölçeği Kısa Formu arasında negatif yönde düşük düzeyde anlamlı ilişki saptanmıştır. Alan yazında maddecilik; yalnızlık (Pieters, 2013), depresyon (Mueller vd., 2011) ve düşük benlik saygısı (Christopher vd., 2006; Richins ve Dawson, 1992) gibi iyi-oluşun birçok negatif göstergesi ile pozitif yönlü ilişsili bulunmuştur. Kasser ve Ryan (2001) tarafından yapılan bir dizi çalışma, yüksek düzeyde maddeci değerlere sahip olan bireylerin daha az olumlu duygu ve daha yüksek düzeyde depresyon, kayg1 ve madde bağımlılığına sahip olduklarını göstermiştir. Alan yazındaki bu çalışmalar, araştırmamızdaki maddecilik ve mutluluk arasındaki negatif korelasyonu destekler niteliktedir. Maddi Değerler Ölçeği'nin alt boyutu olan mutluluk ile Oxford Mutluluk Ölçeği'nden elde edilen mutluluk puanlarının negatif yönlü anlamlı bulunması da maddi değerlerle sağlanan mutluluğun gerçek hayattaki mutluluğun tam tersi bir yönde seyrettiği çıkarımını ortaya çıkarmaktadır. Mutluluk alt boyutlarındaki ifadelerden de anlaşılacağı üzere bir kişinin mal ve varlık sahibi olduğu zaman mutlu olacağ düşüncesi ve imgesinin pratikte karşılığının olmadığını göstermiştir. Bu noktada Tsang ve diğgerleri (2014) üniversite öğrencileri ile gerçekleştirdikleri "neden maddeciler daha az mutlu" isimli çalışmada, maddeciliğin minnettarlık, yaşam doyumu ve ihtiyaç doyumu ile negatif yönlü anlamlı ilişkide olduğunu tespit etmiştir. Bu bulguyu yorumlarken yüksek düzeyde maddeci olan insanların temel psikolojik ihtiyaçlarında azalma olduğu ve bunun da sahip oldukları şeylerden şükran duymamaya yol açtığı, şükran duymayan bireylerin de mutluluk düzeylerinin düşük olduğu şeklinde açıklamışlardır.

Ölçek ve alt boyutlarının puan ortalamalarının orta düzeyde olması, ülkemizdeki yetişkinlerin maddecilik noktasında aşırı uçlarda olmadığı noktasında bir ipucu olarak görülebilir. Ölçeğin iki boyutu olan mutluluk ile merkeziyet ve başarı boyutu arasındaki ilişki orta düzeyde ve anlamlı olarak bulunması ve bu iki boyutun ölçeğin toplam puanı ile yüksek düzeyde anlamlı ilişkide olması da geçerli bir ölçek olduğunu göstermektedir. Güvenirlik ölçümlerinde ise ölçeğin her iki boyutunun da Cronbach alfa katsayısı .70, tüm ölçeğin Cronbach alfa katsayısı .77 bulunmuştur. Ayrıca ölçeğin düzeltilmiş madde-toplam korelasyonlarının .40 ile .61 arasındaki değerlere sahip olduğu tespit edilmiştir. Tüm bu analizler neticesinde ölçeğin güvenilir ve geçerli bir ölçme aracı olduğu kanaatine varılmıştır. Ölçeğin 8 maddeden oluşan kısa bir biçime sahip olması ve 2-3 dakika içinde yanıtlanabilmesi de kullanışlılığının olduğunu göstermektedir.

\section{Sonuç ve Öneriler}

$\mathrm{Bu}$ sonuçlar incelendiğinde ileride yapılacak araştırmalar için bazı öneriler getirilmiştir. Çalışmamız üniversite lisans ve yüksek lisans öğrencilerini kapsadığı için doktora öğrencilerini de kapsayan bir çalışma ile veriler sınanabilir. Ayrıca sadece üniversite değil toplumun farklı kesiminden ve farklı yaş düzeylerine sahip insanlar da çalışma grubunda yer alabilir. Ölçeğin güvenirliğine katkı sağlamak amacıyla test tekrar test uygulaması gerçekleştirilebilir. Ayrıca farklı değişkenler kullanılarak öğrencilerin maddi değer düzeylerinin mutluluk, özsaygı, empati, diğerkâmlık, saldırganlık vb. değişkenler ile ilişkisi incelenebilir. Maddi değer düzeyleri yüksek bireylerin belirlenmesi, uyum bozucu seviyede seyreden durumların incelenmesi ve bu bireylerle gerçekleştirilebilecek çalışmalara katkı sağlayabilmesi açısından ölçeğin önemli olduğu düşünülmektedir. Ölçeğin maddi değerlerin yerine manevi, vicdani, ahlaki değerlerin geliştirilmesi için çalışmalar yapan profesyonel kurum, kuruluşlar için de yarar sağlayacağ öngörülmektedir. 


\section{Kaynakça}

Belk, R. W. (1985). Materialism: trait aspects of living in the material world. J Consum Res. (12). 265-280.

Braithwaite, V. ve Blamey, R. (1998). Consensus, stability and meaning in abstract social values. Australian Journal of Political Science, 33(3), 363-380.

Browne, B. A. ve Kaldenberg, D. O. (1997). Conceptualizing self-monitoring: Links tomaterialism and product involvement. J. Consum.Market.. 14(1): 31-44.

Büyüköztürk, Ş. (2011). Sosyal bilimler için veri analizi el kitabı - İstatistik, araştırma deseni, spss uygulamalart ve yorum (15. Bask1). Ankara: Pegem Akademi

Christopher. A. N., Drummond. K., Jones. J. R., Marek. P. ve Therriault, K. M. (2006). Beliefs about one's own death. personal insecurity. and materialism. Personality and Individual Differences. 40. 441-451. http://dx.doi.org/10.1016/j.paid.2005.09.017.

Csikszentmhalyi, M. ve Rochberg-Halton, E. (1978). Reflections on materialism. University of Chicago Magazine, 70, 6-15.

Csikszentmihalyi, M. ve Rochberg-Halton, E. (1981). The meaning of things: domestic symbols and the self. Cambridge: Cambridge University Press.

Çokluk, Ö.. Şekercioğlu, G. ve Büyüköztürk, Ş.(2012). Sosyal bilimler için çok değişkenli istatistik SPSS ve LISREL uygulamalart. Ankara: Pegem Akademi.

Doğan, T. ve Akıncı-Çötok, N. (2011). Oxford mutluluk ölçeği kısa formunun Türkçe uyarlaması: Geçerlik ve güvenirlik çalışması. Türk Psikolojik Danışma ve Rehberlik Dergisi. 4(36). 165172.

Fraenkel. J. R.. Wallen. N. E.. \& Hyun. H. H. (2012). How to design and evaluate research in education (8. bs.). New York: McGraw Hill.

Goldberg, M. E.. Gorn, G. J.. Peracchio, L. A. ve Bamossy, G. (2003). Understanding materialism among youth. Journalof Consumer Psychology. 13(3). 278-288.

Griffin, M., Babin, B. J. ve Christensen, F. (2004). A cross-cultural 1nvestigation of the materialism construct - Assessing the Richins and Dawson's Materialism Scale in Denmark. France and Russia. Journal of Business Research. 57(8). 893-900

Hanzaee, K. H. ve Adibifard, S. (2012). Development and validation of native material values scale for Iran (NMVS-I). Research Journal of Applied Sciences. Engineering and Technology 4(14): 2140-2146.

Hills, P. ve Argyle, M. (2002). The Oxford Happiness Questionnaire: a compact scale for the measurement ofpsychological well-being. Personality and IndividualDifferences. 33. 10731082.

Kasser, T. \& Ryan, R. M. (2001). Be careful what you wish for: Optimal functioning and the relative attainment of intrinsic and extrinsic goals. In P. Schmuck \& K. M. Sheldon (Eds.). Life goals and well-being: Towards a positive psychology of human striving (pp. 116-131). Ashland. $\mathrm{OH}$ : Hogrefe \& Huber.

Lipovčan, L. K.. Prizmić-Larsen, Z. ve Brkljačić, T. (2015). Materialism. affective states. and life satisfaction: case of Croatia. SpringerPlus. 4. 699. http://doi.org/10.1186/s40064-015-1494-5

Marsh, H. W., Balla, J. R.. ve McDonald, R. P. (1988). Goodness-of-Fit indexes in confirmatory factor analysis: The effect of sample size. Psychological Bulletin, 103(3), 391-410. 
Mueller, A., Mitchell, J. E., Peterson, L. A., Faber, R. J., Steffen, K. J., Crosby, R. D. vd. (2011). Depression. materialism. and excessive internet use in relation to compulsive buying. Comprehensive Psychiatry. $52 . \quad 420-424$. http://dx.doi.org/10.1016/j.comppsych.2010.09.001.

Müller, A., Smits, D. J. M., Claes, L., Gefeller, O., Hinz, A. ve de Zwaan, M. (2013). The German version of the Material Values Scale. GMS Psycho-Social-Medicine. 10. Doc05. http://doi.org/10.3205/psm000095

Opree, J. S., Buijzen. M..,Reijmersdal, E. A. V. ve Valkenburg, M. P. (2011). Development and validation of the material values scale for children (MVS-c). Personality and IndividualDifferences. 51(8). 963-968.

Pieters, R. (2013). Bidirectional dynamics of materialism and loneliness: Not just a vicious cycle. Journal of Consumer Research. 615-631. http://dx.doi.org/10.1086/ 671564.

Richins, M. L. (1994). Special possessions and the expression of material values. Journal of Consumer Research. 21(3). 522-523.

Richins, M. L. (2004). The material values scale: Measurement properties and development of a short form. Journal of Consumer Research. 31(1). 209-219.

Richins, M. L. ve Dawson, S. (1992). A consumer values orientation for materialism and its measurement: Scale development and validation. Journal of Consumer Research.19(3). 303316.

Rokeach, M. (1968) Beliefs, attitudes and values: A theory of organization and change. Exlibrary/underlining edition. San Francisco, CA: Jossey-Bass Inc Pub.

Stevens, J. P. (1992) Applied multivariate statistics for the social sciences (2nd edition). Hillsdale, $\mathrm{NJ}$ : Erlbaum.

Tavşancıl, E. (2010). Tutumların ölçülmesi ve SPSS ile veri analizi. (4. Baskı). Ankara: Nobel yayın Dağıtım

Trochim, W. M. ve Donnelly, J. P. (2006). The research methods knowledge base (3rd ed.). Cincinnati. OH:Atomic Dog.

Tsang, J. A., Carpenter, T. P., Roberts, J. A., Frisch, M. B. ve Carlisle, R. D. (2014). Why are materialists less happy? The role of gratitude and need satisfaction in the relationship between materialism and life satisfaction. Personality and Individual Differences, 64, 62-66.

Wong, N., Rindfleisch, A., ve Burroughs, J. E. (2003). Do reverse-worded 1tems confound measures in cross-cultural consumer research? The case of the material values scale. Journal of Consumer Research, 30(1), 72-91. https://doi.org/10.1086/374697 


\section{Ek 1. Maddi Değerler Ölçeği Formu}

\begin{tabular}{|l|l|l|l|l|l|l|}
\hline & $\begin{array}{l}\text { Lütfen hangi seçenek sizi en iyi } \\
\text { tanımlıyorsa onu işaretleyiniz ve hiçbir } \\
\text { maddeyi boş bırakmayını. }\end{array}$ & $\begin{array}{l}\text { Kesinli } \\
\text { kle } \\
\text { katılmı } \\
\text { yorum }\end{array}$ & $\begin{array}{l}\text { Katılm1 } \\
\text { yorum }\end{array}$ & $\begin{array}{l}\text { Kara } \\
\text { rsızı } \\
\mathrm{m}\end{array}$ & $\begin{array}{l}\text { Katılı } \\
\text { yorum }\end{array}$ & $\begin{array}{l}\text { Kesinli } \\
\text { kle } \\
\text { katılıyo } \\
\text { rum }\end{array}$ \\
\hline $\mathbf{1}$ & $\begin{array}{l}\text { Sahip olmadığım bazı şeylere sahip olsam } \\
\text { hayatım daha iyi olurdu. }\end{array}$ & 1 & 2 & 3 & 4 & 5 \\
\hline $\mathbf{3}$ & $\begin{array}{l}\text { Daha çok şey satın almaya gücüm } \\
\text { yetebilseydi daha mutlu olurdum. }\end{array}$ & 1 & 2 & 3 & 4 & 5 \\
\hline $\mathbf{4}$ & $\begin{array}{l}\text { Beğendiğim şeyleri satın almaya gücümün } \\
\text { yetmemesi canımı sıkıyor. }\end{array}$ & 1 & 2 & 3 & 4 & 5 \\
\hline $\mathbf{5}$ & $\begin{array}{l}\text { Bir şeyler satın almak bana çok keyif } \\
\text { veriyor. }\end{array}$ & 1 & 2 & 3 & 4 & 5 \\
\hline $\mathbf{6}$ & $\begin{array}{l}\text { Pahalı ev, araba ve kıyafetleri olan } \\
\text { insanlara hayranım. }\end{array}$ & 1 & 2 & 3 & 4 & 5 \\
\hline $\mathbf{7}$ & $\begin{array}{l}\text { İnsanları etkileyen şeylere sahip olmayı } \\
\text { seviyorum. }\end{array}$ & 1 & 2 & 3 & 4 & 5 \\
\hline $\mathbf{8}$ & $\begin{array}{l}\text { Hayatımda birçok lüks şey olmasını } \\
\text { seviyorum. }\end{array}$ & 1 & 2 & 3 & 4 & 5 \\
\hline $\mathbf{9}$ & $\begin{array}{l}\text { Bir şeylere sahip olma söz konusu } \\
\text { olduğunda hayatımı sade sürdürmeye } \\
\text { çalışırım. }\end{array}$ & 1 & 2 & 3 & 4 & 5 \\
\hline
\end{tabular}

NOT: Bilimsel çalışmalarda kaynak gösterilmek şartıyla izin alınmadan kullanılabilir.

NOT2: Ölçekte 9. Madde ters madde olarak kodlanmaktadır. 1.3.4. Maddeler "Mutluluk"; 5.6.7.8 ve 9. Maddeler ise "Merkezilik ve Başarı" alt boyutunda yer almaktadır.

\section{ETİK ve BİLIMSEL İLKELER SORUMLULUK BEYANI}

$\mathrm{Bu}$ çalışmanın tüm hazırlanma süreçlerinde etik kurallara ve bilimsel atıf gösterme ilkelerine riayet edildiğini yazar(lar) beyan eder. Aksi bir durumun tespiti halinde Afyon Kocatepe Üniversitesi Sosyal Bilimler Dergisi'nin hiçbir sorumluluğu olmayıp, tüm sorumluluk makale yazarlarına aittir. 